\title{
Atopic Dermatitis Deteriorates Dextran Sodium Sulfate-Induced Ulcerative Colitis via Thymic Stromal Lymphopoietin in Mice
}

\author{
Keiichi Hiramoto¹, Kumi Orita², Yurika Yamate'1, Satoshi Yokoyama3 \\ ${ }^{1}$ Department of Pharmaceutical Sciences, Suzuka University of Medical Science, Suzuka, Japan \\ ${ }^{2}$ Department of Orthopedic Surgery, Osaka City University Graduate School of Medicine, Osaka, Japan \\ ${ }^{3}$ Department of Pharmaceutical Sciences, Gifu Pharmaceutical University, Gifu, Japan \\ Email: hiramoto@suzuka-u.ac.jp
}

How to cite this paper: Hiramoto, K., Orita, K., Yamate, Y. and Yokoyama, S. (2017) Atopic Dermatitis Deteriorates Dextran Sodium Sulfate-Induced Ulcerative Colitis via Thymic Stromal Lymphopoietin in Mice. Journal of Biosciences and Medicines, 5, 8598. https://doi.org/10.4236/jbm.2017.53009

Received: February 8, 2017

Accepted: March 20, 2017

Published: March 23, 2017

Copyright $\odot 2017$ by authors and Scientific Research Publishing Inc. This work is licensed under the Creative Commons Attribution International License (CC BY 4.0).

http://creativecommons.org/licenses/by/4.0/

\begin{abstract}
It has been reported that atopic dermatitis $(\mathrm{AD})$ and ulcerative colitis are related. However, the mechanism underlying this association has not been clarified. We therefore explored how $\mathrm{AD}$ induces ulcerative colitis. We developed an $\mathrm{AD}$ mouse model (NC/Nga mice) with ulcerative colitis by administering dextran sodium sulfate (DSS) for five days. DSS-induced ulcerative colitis was deteriorated in our conventional $\mathrm{AD}$ mouse model compared with specificpathogen-free (SPF) mice. The plasma levels of thymic stromal lymphopoietin (TSLP) and tumor necrosis factor- $\alpha$ increased the most in DSS-treated conventional mice. Furthermore, the expression of dendritic cells (DC), retinoidrelated orphan receptor (ROR) $y t$ (marker of $\mathrm{T}$ helper 17 cells [Th17]), interleukin (IL)-17, GATA binding protein 3 (GATA3) (marker of Th2), and IL-4 increased the most in the colon of the DSS-treated conventional mice compared with DSS-treated SPF mice. In addition, TSLP inhibitor (TSLP neutralizing antibody) did not exacerbate ulcerative colitis in DSS-treated conventional mice. These results indicate that TSLP/DC/Th2 and Th17 play major roles in the exacerbation of ulcerative colitis by AD.
\end{abstract}

\section{Keywords}

DSS-Induced Ulcerative Colitis, Atopic Dermatitis, Thymic Stromal Lymphopoietin, Dendritic Cell, T Helper 2 Cell, T Helper 17 Cell

\section{Introduction}

Although the number of patients with ulcerative colitis has increased rapidly in recent years, the cause of this disease remains unclear. Ulcerative colitis results in the decomposition and ulcer formation in the stratum mucosum or in the 
substratum of the tunica-mucosa of the colon. Clinical symptoms include loose intestines, bloody feces, celialgia and weight loss. In addition, the invasion of inflammatory cells and a decrease in the population of germinal cells and crypt abscess have been reported as histological findings [1] [2] [3]. Studies on the pathogenic mechanism have described changes in the pathogenic-recognition sensors, such as toll-like receptor (TLR), nucleotide-binding and oligomerization domain (NOD) [4], along with the influence of natural-immunity cells, such as dendritic cells (DCs), macrophages and natural killer (NK) cells in the digestive-tract tunica mucosa [5], as well as changes in the intestinal flora [6]. Environmental agents such as stress have also been implicated [7].

Atopic dermatitis (AD) is dermatitis that passes chronically following itchiness. Symptoms include dry skin and fundamental deviations in the barrier function, and various stimulants and allergens have been reported to induce the development of $\mathrm{AD}$. In addition, many $\mathrm{AD}$ patients have atopic disposition, and stress has been suggested as a deteriorative agent [8]. New mechanisms underlying $\mathrm{AD}$ have recently been reported, such as the onset of allergy due to thymic stromal lymphopoietin (TSLP), thymus and activation-regulated chemokine (TARC) and basophils [9] [10]; the breakdown of the skin barrier function due to decreases in filaggrin [11]; and the exacerbation of itchiness due to interleukin (IL)-31 [12].

The relation between $\mathrm{AD}$ and ulcerative colitis is studied and it is reported that AD increases risk of an ulcerative colitis [13] [14]. Furthermore, AD and ulcerative colitis share a common pathopoiesis factor. For example, both are associated with increases in levels of TSLP, tumor necrosis factor (TNF)- $\alpha$, IL-4 and DCs. Therefore, AD and ulcerative colitis may be related. However, few reports have examined the influence of $\mathrm{AD}$ on ulcerative colitis. In this study, we explored the association between $\mathrm{AD}$ and dextran sodium sulfate (DSS)-induced ulcerative colitis in NC/Nga mice, a mouse model of AD.

\section{Materials and Methods}

\subsection{Animal Experiments}

Specific-pathogen-free (SPF) and conventional NC/Nga male mice (9 weeks old) were obtained from SLC (Hamamatsu, Japan). They were housed in rooms at 23 $\pm 1^{\circ} \mathrm{C}$, and the SPF mice were housed under SPF conditions. These animals were subjected to experiments in accordance with the animal care regulations of Osaka City University Medical Science. All surgeries were performed under pentobarbital anesthesia, and all possible efforts were made to minimize suffering. Conventional mice spontaneously started to exhibit symptoms characteristic of $\mathrm{AD}$ at 7 weeks of age (under air-uncontrolled, conventional circumstances). As expected, all of the conventional NC/Nga mice used for this experiment displayed $\mathrm{AD}$-like symptoms. The $\mathrm{AD}$ symptom score in the conventional mice was determined based on their severity of edema, erythema and hemorrhage ( 0 , none; 1 , slight; 2 , moderate; 3 , severe) as described previously [15]. We established the following four groups $(\mathrm{n}=$ six mice each) and used all of the mice at the same 
time: SPF mice, conventional mice with AD, DSS-treated SPF mice and DSStreated conventional mice. To induce ulcerative colitis, we administered $5.0 \%$ (W/V) DSS (molecular weight: 36,000 - 50,000 Da; MP Biomedicals, Solon, OH, USA) via the drinking water of the SPF and conventional mice in the DSStreated groups for 5 consecutive days. The development of colitis was monitored in each mouse by observing their feces. The severity of colitis was determined by assessing the feces condition and colon length. The fecal condition was scored using two parameters: stool consistency $(0=$ normal; $1=$ soft; $2=$ very soft but formed; 3 = liquid $)$ and fecal bleeding $(0=$ negative; $1=$ faintly blue; $2=$ moderately blue; 3 = dark blue; 4 = blood visible using the guaiac paper test), with the sum considered to be the animal's disease activity score [16]. In addition, we use six mice per group, and each experiment was repeated three times.

\subsection{TSLP Antibody Treatment}

We used the mouse TSLP antibody (R\&D Systems, Minneapolis, MN, USA), in order to inhibit TSLP activity in mice. This antibody is used as a neutralizing antibody. TSLP antibody $(0.4 \mu \mathrm{g} / \mathrm{ml} /$ day $)$ was suspended in phosphate-buffered saline (PBS), which was intraperioneally injected on each day of the experiment in DSS-treated SPF and conventional mice [17].

\subsection{Preparation and Staining of the Skin and Colon}

For the histological studies, mice were sacrificed five days after the start of the experiment. Skin and colon specimens were fixed in PBS containing 4\% paraformaldehyde, embedded in frozen Tissue Tek, OCT compound (Sakura Finetek, Tokyo, Japan), and cut into 5 - $\mu$ m-thick sections. The sections were stained with hematoxylin-eosin (HE) in accordance with the established procedure for the histological analysis of the tissue.

Skin and colon specimens were also subjected to immunostaining. We described the details of the staining method in our previous report [18]. Briefly, the specimens were incubated overnight at $4^{\circ} \mathrm{C}$ with one of the following primary antibodies: rat monoclonal anti-I-A/I-E (marker of DCs, 1:100; BD Biosciences, San Jose, CA, USA), rabbit monoclonal anti-GATA binding protein 3 (GATA3) (marker of T helper [Th]-2, 1:100; Cell Signaling Technology Inc., Danvers, MA, USA) and rabbit polyclonal anti-retinoid-related orphan receptor (ROR) $\gamma t$ (marker of Th17, 1:100; Biorbyt, Cambridge, UK). The specimens were then incubated at room temperature for $2 \mathrm{~h}$ with fluorescein isothiocyanate-conjugated (FITC) anti-goat or anti-rabbit immunoglobulin (both used at 1:30; DakoCytomation, Glostrup, Demmark). The protein expression was evaluated immunohistochemically using a fluorescence microscope. The number of I-A/I-E-positive cells was determined using the software program Image J (National Institute of Health, Bethesda, MD, USA).

\subsection{Western Blotting Analysis}

The colon samples were homogenized in Lysis buffer (Kurabo, Osaka, Japan), 
and centrifuged at $8000 \mathrm{~g}$ for 10 minutes. The supernatant from each samples were then isolated and stored at $-80^{\circ} \mathrm{C}$ until the analysis. We performed a Western blotting analysis as previously described [19]. Briefly, the membranes were incubated at $25^{\circ} \mathrm{C}$ for $1 \mathrm{~h}$ with primary antibodies against GATA3 (1:1000; Cell Signaling Technology Inc.), IL-4 (1:1000; Caltag Laboratories, Carlsbad, CA, USA), ROR $\gamma$ (1:1000; Biorbyt) and IL-17 (1:1000; Aviva Systems Biology, San Diego, CA, USA) or $\beta$-actin (1:5000; Sigma-Aldrich, St. Louis, MO, USA). The membranes were then treated with a horseradish peroxidase-conjugated secondary antibody (Novex, Frederick, MD, USA). The immune complexes were detected using ImmunoStar Zeta regent (Wako, Osaka, Japan), and images were acquired using the Multi-Gauge software program (Fujifilm, Greenwood, SC, USA).

\subsection{Enzyme-Linked Immunosorbent Assay (ELISA) Analysis of Plasma Immunoglobulin E (IgE), Tumor Necrosis Factor (TNF)- $\alpha$, TSLP and Interferon (IFN)- $\gamma$ Levels}

Blood samples were taken from the heart on the fifth day after the start of DSS treatment. The plasma levels of IgE, TNF- $\alpha$, TSLP and IFN- $\gamma$ were determined using commercial ELISA kits (IgE: YamasaShoyu Co., Ltd., Chiba, Japan; TNF$\alpha$, IFN- $\gamma$ and TSLP: R\&D systems) in accordance with the manufacture's instructions. The optical density was measured with a microplate reader (Molecular Devices, Sunnyvale, CA, USA).

\subsection{Statistical Analyses}

All data are presented as the means \pm standard deviation. Results were statistically analyzed using Microsoft Excel 2010 and a one way analysis of variance (ANOVA) followed by Tukey's post hoc test using the software program SPSS, version 20. Results were considered significant at $\mathrm{p}<0.05$.

\section{Results}

\subsection{Evaluation of the Severity of AD}

No symptoms associated with $\mathrm{AD}$ were observed after 5 days of DSS-treatment in SPF mice. In contrast, the conventional mice exhibited marked symptoms characteristic of $\mathrm{AD}$, including edema, erythema and hemorrhaging of their rostral skin. DSS administration resulted in no marked differences in the presence of such symptoms (Figure 1(a)). The morphological findings are shown in Figure 1(b). No marked differences in histopathological changes were detected between the non-treated and DSS-treated SPF mice. In the conventional mice, notable acanthosis, hyperplasia of the epidermis, ulceration and infiltration of large numbers of lymphocytes in the dermis were evident. Of note, DSS administration resulted in no marked differences in the presence of such changes.

\subsection{Effect of AD in DSS-Treated Mice}

Diarrhea and fecal bleeding were observed after DSS-treatment in both SPF and 


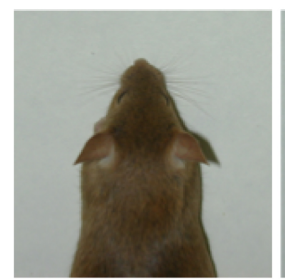

SPF

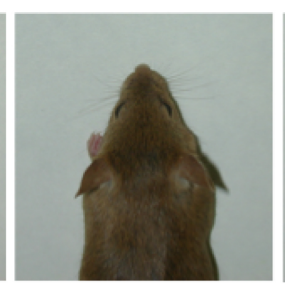

SPF + DSS

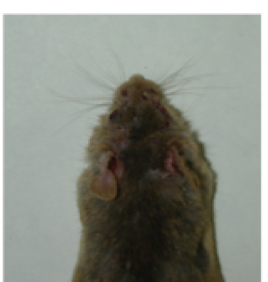

Conv

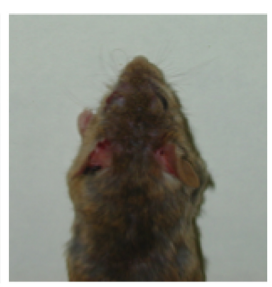

Conv + DSS

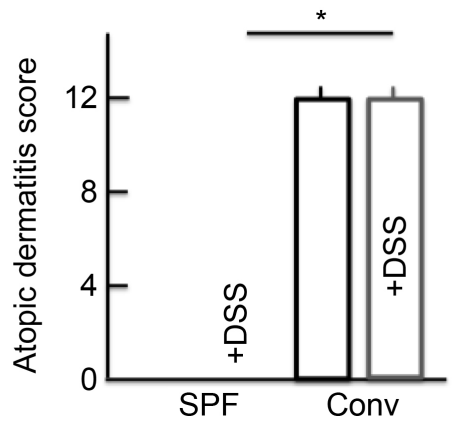

(a)

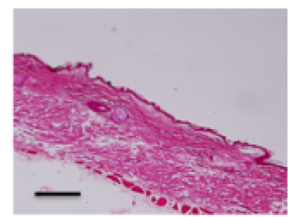

SPF

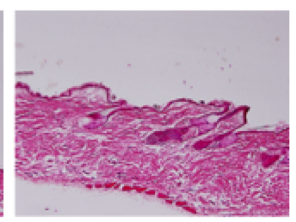

SPF + DSS

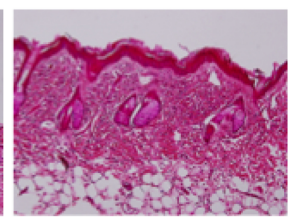

Conv

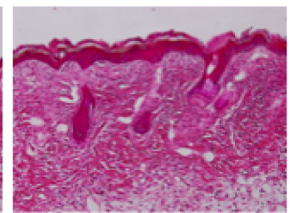

Conv + DSS

(b)

Figure 1. Skin symptoms, atopic dermatitis scores, and histological analysis of skin. (a) Skin symptoms and atopic dermatitis scores after treatment with 5.0\% DSS for 5 consecutive days. (b) A histological analysis of skin tissue sections after treatment with $5.0 \%$ DSS for 5 consecutive days. SPF: specific-pathogen-free, conv: conventional. The values are expressed as the mean \pm SD derived from 6 animals. ${ }^{*} \mathrm{p}<0.05$.

conventional NC/Nga mice. However, the activity scores in the DSS-treated conventional mice were higher than in the DSS-treated SPF mice; the scores in both groups of untreated mice were 0 (Figure 2(a)). DSS treatment also resulted in a dramatic decrease in the colon length. The colon length in the DSS-treated conventional mice was shorter than in the DSS-treated SPF mice, while the colon length in both groups of untreated mice was roughly the same (Figure 2(a)). H\&E staining also highlighted the cellular distraction of the intestinal epithelium in the colon of DSS-treated mice as well as edema in the submucosa. The state of the colon was more severe in the DSS-treated conventional mice than in the DSS-treated SPF mice, while the colon of both groups of untreated mice was relatively normal (Figure 2(b)).

\subsection{Effects of AD on the Plasma Levels of IgE, TNF- $\alpha$, IFN- $\gamma$ and TSLP in DSS-Treated NC/Nga Mice}

We performed ELISA assays to measure the plasma levels of IgE, TNF- $\alpha$ and IFN- $\gamma$ in the DSS-treated mice after five days of treatment. We found that the 


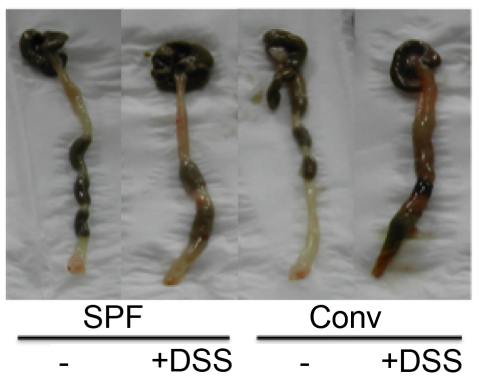

(a)
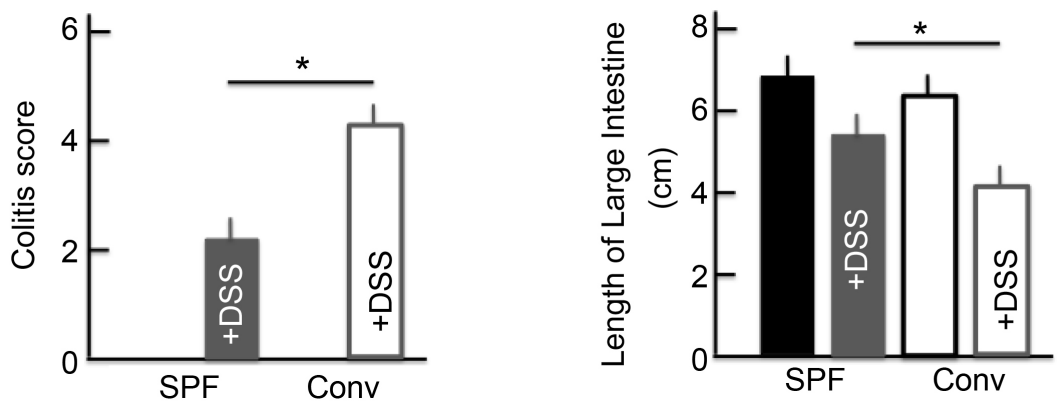

5 days after DSS treatment

(b)

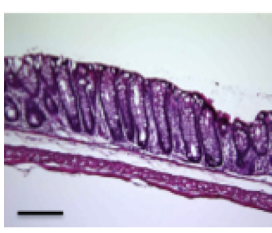

SPF

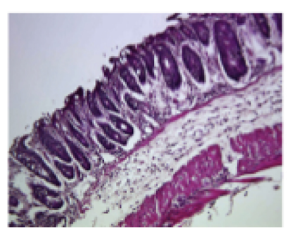

SPF + DSS

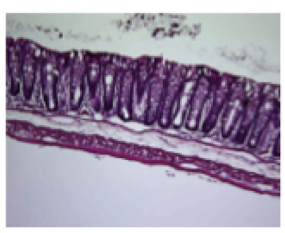

Conv

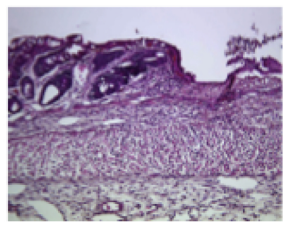

Conv + DSS

(c)

Figure 2. Effects of atopic dermatitis (AD) on DSS-induced ulcerative colitis. The temporal response of the colitis score (a). The length of the large intestine (b) after treatment with $5.0 \%$ DSS for 5 consecutive days. A histological analysis of the colon (c) after treatment with $5.0 \%$ DSS for 5 consecutive days. Scale bar $=100 \mu \mathrm{m}$. The values are expressed as the mean \pm SD derived from 6 animals. ${ }^{\star} \mathrm{p}<0.05$. SPF: specific-pathogen-free, conv: conventional, each groups, $\mathrm{n}=6$.

plasma levels for each protein were significantly higher in both groups of DSS-treated mice and in untreated conventional mice than in untreated SPF mice. In the conventional mice, the levels of IgE, TNF- $\alpha$ and TSLP were higher than in the SPF mice. Furthermore, the TNF- $\alpha$ and TSLP levels in the DSStreated conventional mice were higher than in either group of untreated mice. No marked differences in the levels of IgE were noted between DSS-treated and untreated mice. However, while the levels of IFN- $\gamma$ did not markedly differ between the DSS-treated mice and the untreated conventional mice, the levels were significantly higher in the untreated SPF mice (Figure 3).

\subsection{Effects of AD on the Expression of DCs in DSS-Treated Mice}

Next, we investigated the expression of DCs in the colon. DC expression was higher in the colon of DSS-treated mice than in untreated mice. In addition, 


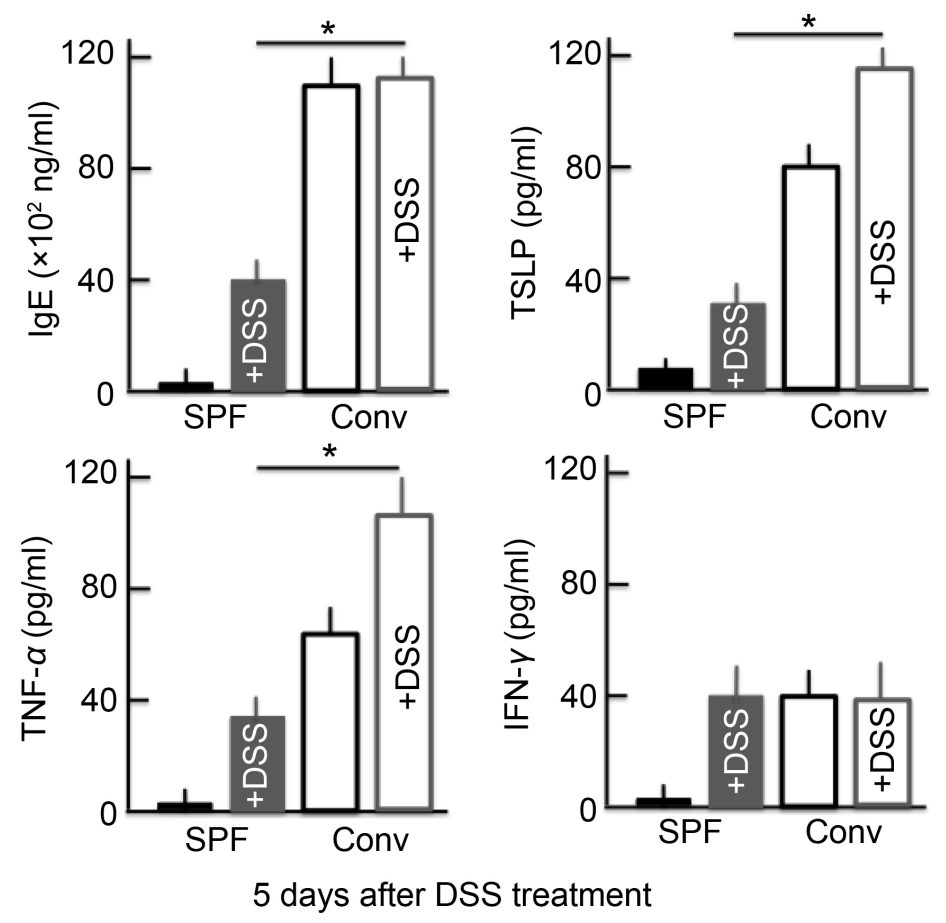

Figure 3. An analysis of the plasma IgE, TSLP, TNF- $\alpha$ and IFN- $\gamma$ concentrations after treatment with $5 \%$ DSS for 5 consecutive days. The values are expressed as the mean \pm SD derived from 6 animals. ${ }^{*} \mathrm{p}<0.05$. SPF: specific-pathogen-free, conv: conventional.

among the DSS-treated mice, the DC expression was higher in the colon of conventional mice than in SPF mice (Figure 4).

\subsection{Effects of AD on the Expression of GATA3 and IL-4 in DSS-Treated NC/Nga Mice}

We investigated the expression of Th2 cells activated by DCs. GATA 3 was used as a marker of Th2 cells [20]. The expression of Th2 cells in the colon of DSStreated mice was higher than in untreated mice. In addition, among the DSStreated mice, the Th2 cell expression was higher in the colon of conventional mice than in SPF mice (Figure 5(a)). We also examined the expression of IL-4, which has a close relationship with Th2 cells. We observed similar trends in the expression of IL-4 in the colon as for Th2 cells (Figure 5(b)).

\subsection{Effects of AD on the Expression of ROR $\gamma \mathrm{t}$ and IL-17 in DSS-Treated NC/Nga Mice}

We also investigated the expression of Th17 cells activated by TSLP. ROR $\gamma t$ was used as a marker of Th17 cells [21]. The expression of Th17 cells in the colon of DSS-treated mice was higher than in untreated SPF mice. In addition, the expression was highest in DSS-treated conventional mice (Figure 6(a)). We then examined the expression of IL-17, which has a close relationship with Th17 cells. We observed similar trends in the expression of IL-17 in the colon as for Th17 cells (Figure 6(b)). 


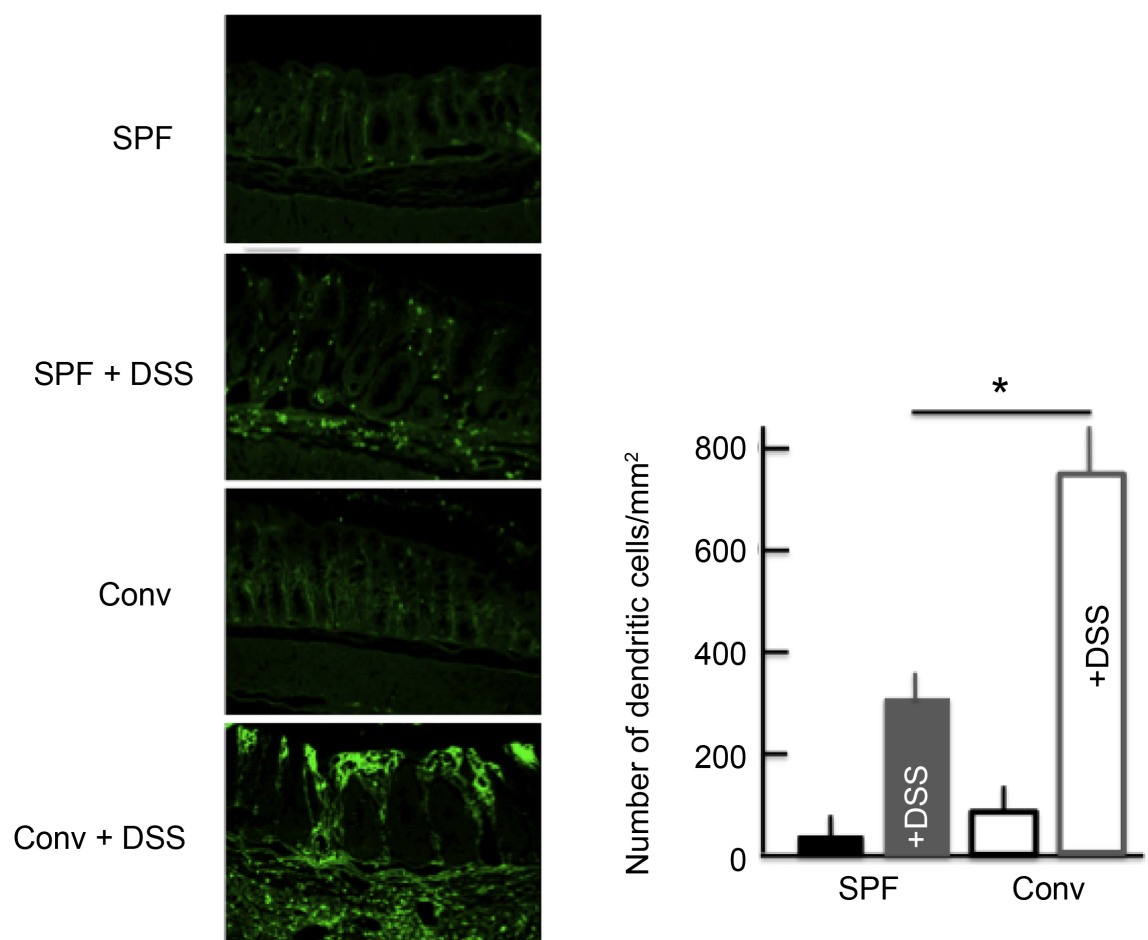

Figure 4. The effect of DSS treatment on the expression of dendritic cells (DCs) in the colon. An immunohistochemical analysis of DCs and stained DC counts in the colon after treatment with $5.0 \%$ DSS for 5 consecutive days. The values represent the means \pm SD derived from 6 animals. ${ }^{*} \mathrm{p}<0.05$. Scale bar $=100 \mu \mathrm{m}$. SPF: specific-pathogen-free, conv: conventional.

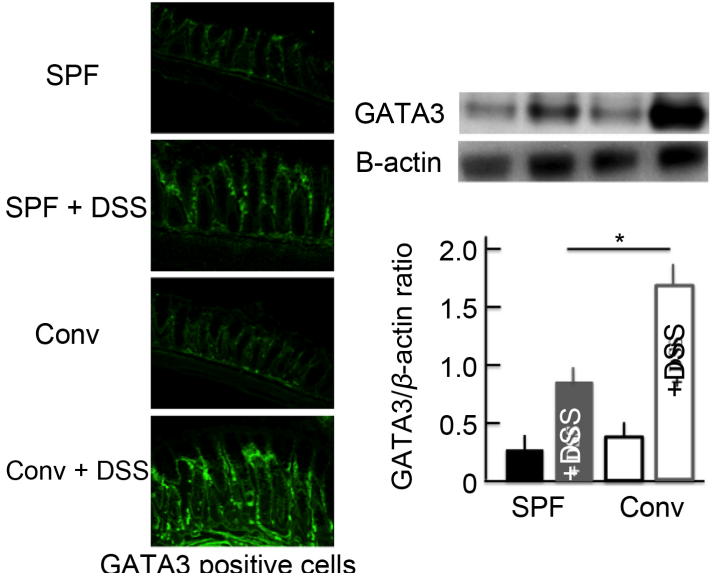

(a)
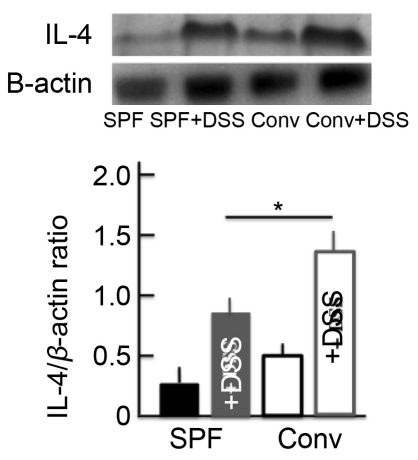

(b)

Figure 5. The effect of DSS treatment on the expression of Th2 cells and IL-4 in the colon. An immunohistochemical analysis of Th2 cells (a) and a Western blotting analysis for Th2 cells and IL- 4 in the colon (b) after treatment with 5.0\% DSS for 5 consecutive days. The values are expressed as the mean \pm SD derived from 6 animals. ${ }^{*} \mathrm{p}<0.05$. Scale bar $=100 \mu \mathrm{m}$. SPF: specific-pathogen-free, conv: conventional.

\subsection{AD Symptoms in DSS-Treated NC/Nga Mice after Anti-TSLP Injection}

The colitis score and the shortening of the colon length improved in DSS-treated 


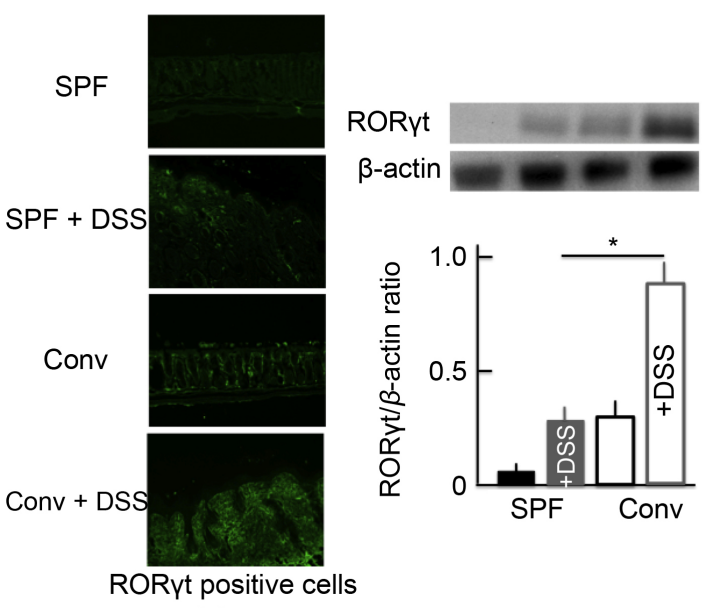

(a)

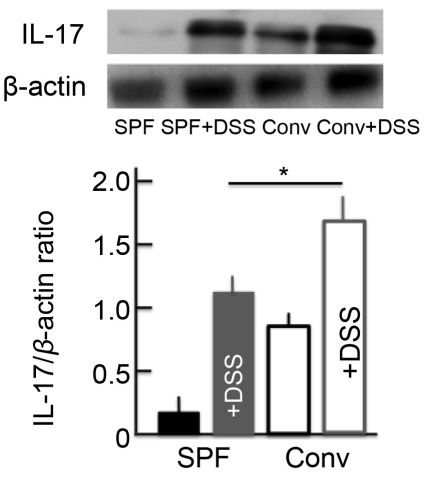

(b)

Figure 6. The effect of DSS-treatment on the expression of Th17 cells and IL-17 in the colon. An immunohistochemical analysis of Th17 cells (a) and a Western blotting analysis for Th17 cells and IL-17 in the colon (b) after treatment with 5.0\% DSS for 5 consecutive days. The values represent the mean \pm SD derived from 6 animals. ${ }^{*} \mathrm{p}<0.05$. Scale bar $=100 \mu \mathrm{m}$. SPF: specific-pathogen-free, conv: conventional.

conventional mice after anti-TSLP treatment. However, no marked difference was noted before and after anti-TSLP administration in DSS-treated SPF mice, DSS- and anti-TSLP-treated SPF mice, and DSS and anti-TSLP-treated conventional mice (Figure 7(b)). Anti-TSLP administration did not appear to ameliorate the $\mathrm{AD}$ symptoms in the untreated conventional mice (Figure $7(\mathrm{a})$ ).

\section{Discussion}

The present study demonstrated that $\mathrm{AD}$ causes the deterioration of DSS-induced ulcerative colitis. The levels of TSLP and TNF- $\alpha$ in the blood of DSStreated conventional mice were increased more than in the other experimental groups. Furthermore, the expression of DCs, Th2 cells, Th17 cells, IL-4 and IL-17 in the colon in DSS-treated conventional mice was higher than in the other groups. However, the symptoms of ulcerative colitis were ameliorated by treatment with TSLP inhibitor in DSS-treated conventional mice to the level observed in DSS-treated SPF mice.

DSS induces the development of intestinal-mucosa epithelium lesions by a kind of a mucopolysaccaride. DSS penetrates to the tunica-mucosa substratum, and antigen-presenting cells (APCs) carry out phagocytosis at that site. The APCs activated by the phagocytosis induce the activation of $\mathrm{T}$ cells, causing symptoms similar to those of inflammatory bowel disease [22]. Activated DCs, which are a type of APCs, increase the expression of IgE, TNF- $\alpha$ and TSLP (Figure 3 and Figure 4). This increase in TSLP induces tunica-mucosa barrier lesions [23], thereby activating DCs, which DSS induces reinforces further. In addition to this vicious cycle, TSLP is produced by epithelial cells due to allergosis and acts on innate immunity systems, such as DCs, mast cells (MCs)and NKT cells [24] [25] [26]. Thus, the activation of is reinforced several-fold DCs by ulcerative colitis and $\mathrm{AD}$ (Figure 4 ). 

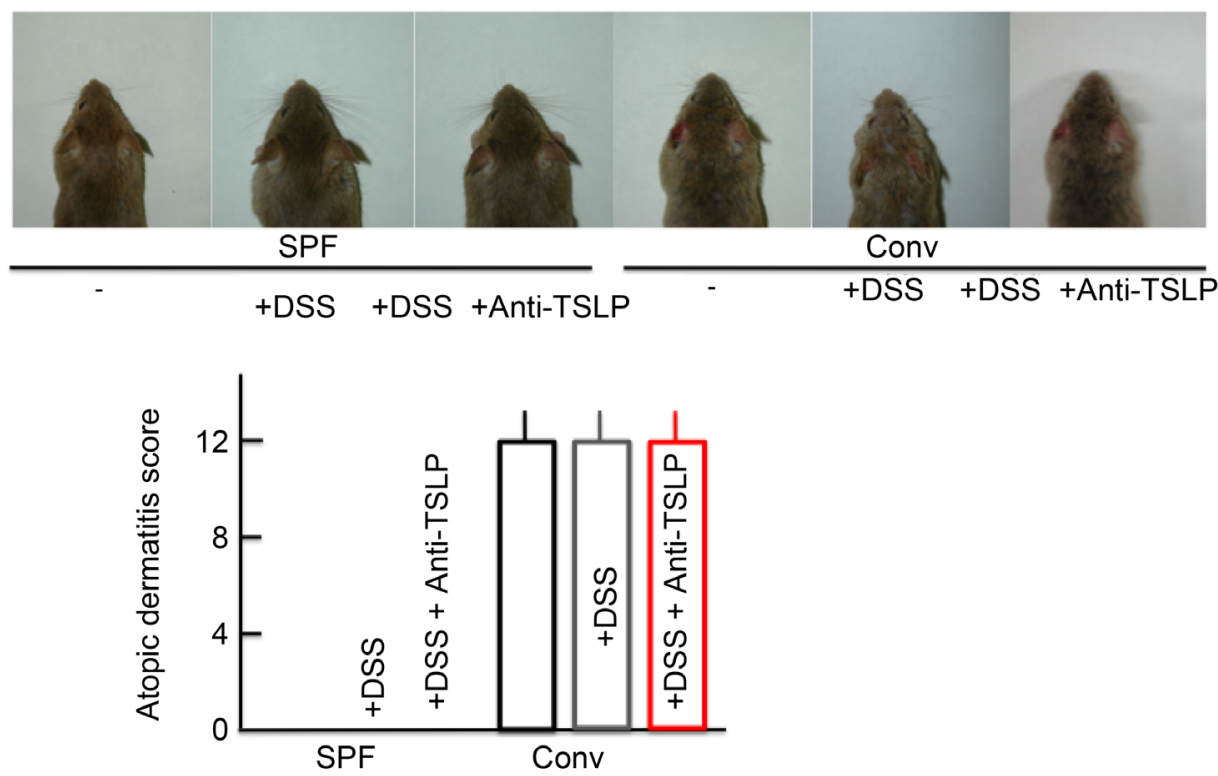

(a)

b

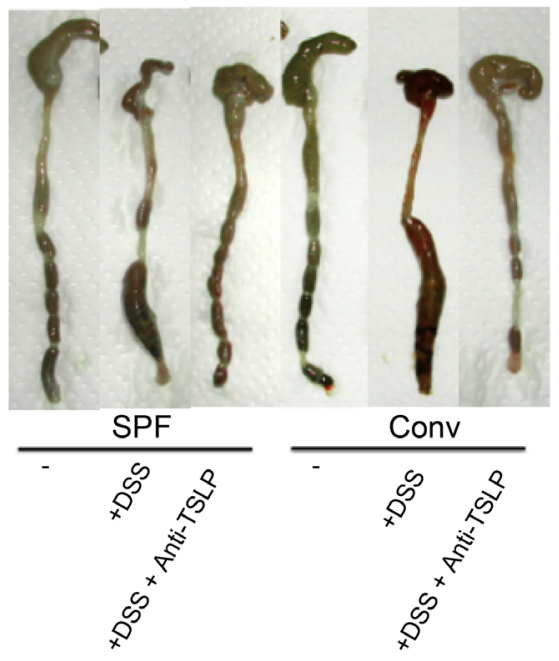

(b)
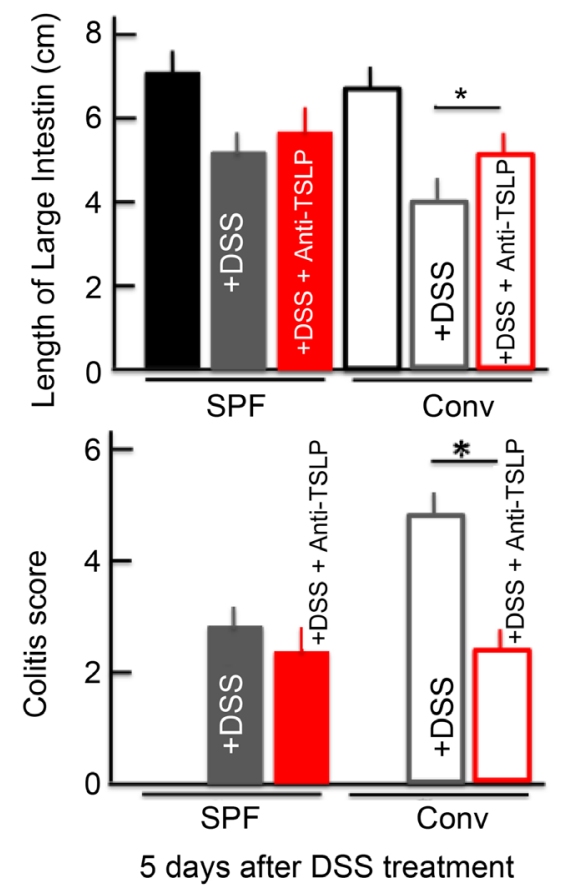

Figure 7. The effect of TSLP inhibitor on the skin symptoms and atopic dermatitis score (a), and the colitis score and length of the large intestine (b). Each parameters was measured after treatment with 5.0\% DSS for 5 consecutive days. TSLP inhibitor (TSLP antibody) was itraperitoneally injected on each day of the experiment. The values represent the mean \pm SD derived from 6 animals. ${ }^{*} \mathrm{p}<0.05$. SPF: specific-pathogen-free, conv: conventional.

Th1 cells are not produced by this cycle, as the induced TSLP suppresses the production of IL-12. Furthermore, IL-4, IL-5 and IL-13 are produced from MCs and basophilic leukocytes by TSLP released from epithelial cells. DCs, which matured in such situations, selectively induce Th2 cells [27] [28]. The inflammatory cytokine released from these Th2 cells exacerbates ulcerative colitis [29]. 
We further observed an increase in the expression of IL- 4 and Th2 cells in the colon in the present study (Figure 5). These findings in our AD model mice suggest that the pathway of TSLP/DC/Th2 cells becomes activated by DSS, subsequently deteriorating ulcerative colitis. We also observed an increase in the expression of Th17 cells and IL-17 in this study (Figure 6). TSLP produced by DCs is reported to control the expression of Th17 cells [30] [31]: TSLP combines with the TSLP receptor (TSLPR), which regulates Th17 cell via the activation and phosphorylation of signal transducer and activation of transcription 5 ( $\mathrm{p}$ STAT5). The activation of Th17 cells may have been induced by activated DCs, with activated Th17 cells increasing the expression of IL-17 and thereby exacerbating inflammation. TSLP also activates regulatory T cells (Tregs) [32]. However, in the present study, we did not evaluate the expression of Treg cells; further examination is necessary.

In this study, the DSS-induced ulcerative colitis in our AD model was ameliorated by the administration of an inhibitor of TSLP (Figure 7). These findings suggest that the strong expression of TSLP badly influences other diseases in AD patients. Of note, no previous report has observed any relationship between the severity of illness and TSLP levels in AD subjects [33]. We also observed no marked changes in the $\mathrm{AD}$ symptoms following the administration of a TSLP inhibitor.

\section{Conclusion}

In this study, the deterioration of DSS-induced ulcerative colitis was observed in $\mathrm{AD}$ model mice. Our findings suggested that TSLP played a major role in this deterioration (Figure 8). Based on these results, we may be able to establish a

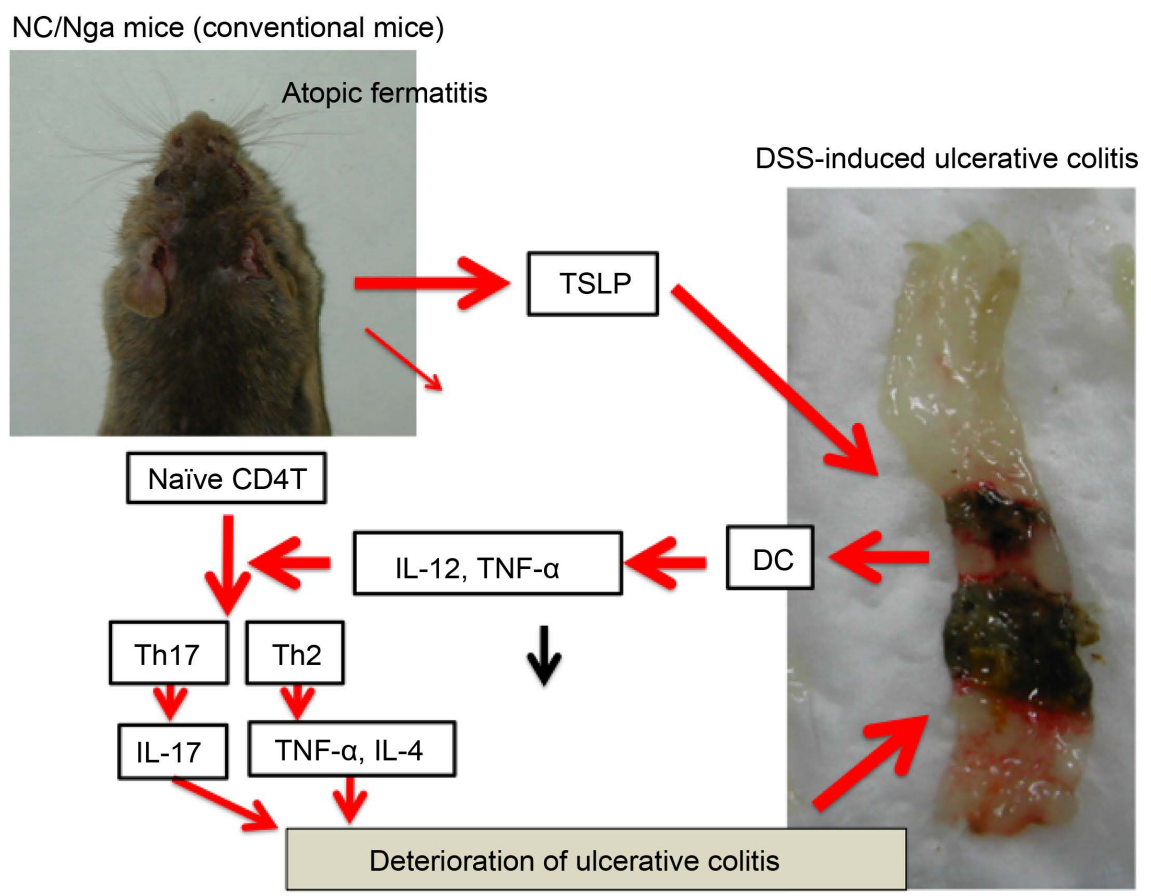

Figure 8. The mechanism of the effect of TSLP on DSS-treated NC/Nga mice. 
therapy for ulcerative colitis in $\mathrm{AD}$ patients. We believe that these findings may be useful for clarifying the causes of and developing treatments for a number of diseases afflicting $\mathrm{AD}$ patients.

\section{Declaration of Interest}

The authors declare no conflicts of interest in association with this study. The authors alone are responsible for the content of this manuscript.

\section{References}

[1] Dilawari, J.B., Parkinson, C., Riddell, R.H., Loose, H. and Williams, C. (1973) Colonoscopy in the Investigation of Ulcerative Colitis. Gut, 14, 426.

[2] Buffinton, G.D. and Doe, W.F. (1995) Altered Ascorbic Acid Status in the Mucosa from Inflammatory Bowel Disease Patients. Free Radical Research, 22, 131-143. https://doi.org/10.3109/10715769509147535

[3] Kullmann, F., Messmann, H., Alt, M., Gross, V., Bocker, T., Scholmerich, J. and Ruschoff, J. (2001) Clinical and Histopathological Features of Dextran Sulfate Sodium Induced Acute and Chronic Colitis Associated with Dysplasia in Rats. International Journal of Colorectal Disease, 16, 238-246.

https://doi.org/10.1007/s003840100311

[4] Fan, Y. and Liu, B. (2015) Expression of Toll-Like Receptors in the Mucosa of Patients with Ulcerative Colitis. Experimental and Therapeutic Medicine, 9, 14551459. https://doi.org/10.3892/etm.2015.2258

[5] Bar-On, L., Zigmond, E and Jung, S. (2011) Management of Gut Inflammation through the Manipulation of Intestinal Dendritic Cells and Macrophages? Seminars in Immunology, 23, 58-64. https://doi.org/10.1016/j.smim.2011.01.002

[6] Ohkusa, T. and Koido, S. (2015) Intestinal Microbiota and Ulcerative Colitis. Journal of Infection and Chemotherapy, 21, 761-768.

https://doi.org/10.1016/j.jiac.2015.07.010

[7] Iglesias-Rey, M., Barreiro-de Acosta, M, Caamano-Isorna, F., Rodriguez, I.V., Ferreiro, R., Lindkvist, B., Gonzalez, A.L. and Dominguez-Munoz, J.E. (2014) Psychological Factors Are Associated with Changes in the Health-Related Quality of Life in Inflammatory Bowel Disease. Inflammatory Bowel Diseases, 20, 92-102.

[8] Japanese Dermatological Association Atopic-Dermatitis Clinical Practice Guideline Creation Committee (2016) Atopic Dermatitis Clinical Practice Guideline 2016. Japanese Journal of Dermatology, 126, 121-155.

[9] Palmer, C.N., Irvine, A.D., Terron-Kwiatkowski, A., Zhao, Y., Liao, H., Lee, S.P., Goudie, D.R., Sandilands, A., Campbell, L.E., Smith, F.J., O’Regan, G.M., Watson, R.M., Cecil, J.E., Bale, S.J., Compton, J.G., DiGiovanna, J.J., Fleckman, P., Lewis-Jones, S., Arseculeratne, G., Sergeant, A., Munro, C.S., El Houate, B., McElreavey, K., Halkjaer, L.B., Bisgaard, H., Mukhopadhyay, S. and McLean, W.H. (2006) Common Loss-of-Function Variants of the Epidermal Barrier Protein Filaggrin Are a Major Predisposing Factor for Atopic Dermatitis. Nature Genetics, 38, 441-446. https://doi.org/10.1038/ng1767

[10] Nakajima, S., Igyarto, B.Z., Honda, T., Egawa, G., Otsuka, A., Hara-Chikuma, M., Watanabe, N., Ziegler, S.F., Tomura, M., Inaba, K., Miyachi, Y., Kaplan, D.H. and Kabashima, K. (2012) Langerhans Cells Are Critical in Epicutaneous Sensitization with Protein Antigen via Thymic Stromal Lymphopoietin Receptor Signaling. Journal of Allergy and Clinical Immunology, 129, 1048-1055.

https://doi.org/10.1016/j.jaci.2012.01.063 
[11] Otuka, A., Nakajima, A., Kubo, M., Wgawa, G., Honda, T., Kitoh, A., Nomura, T., Hanakawa, S., SagitaMoniaga, C., Kim, B., Matsuoka, S., Watanabe, T., Miyachi, Y. and Kabashima, K. (2013) Basophils Are Required for the Induction of Th2 Immunity to Haptens and Peptide Antigens. Nature Communications, 4, Article No. 1738.

[12] Kato, A., Fujii, E., Watanabe, T., Takashima, Y., Matsushita, H., Furuhashi, T. and Morita, A. (2014) Distribution of IL-13 and Its Receptor Expressing Cells in Skin of Atopic Dermatitis. Journal of Dermatological Science, 74, 229-235.

https://doi.org/10.1016/j.jdermsci.2014.02.009

[13] Schmitt, J., Schwarz, K., Baurecht, H., Hotze, M., Folster-Holst, R., Rodriguez, E., Lee, Y.A., Franke, A., Degenhardt, F., Lieb, W., Gieger, C., Kabesch, M., Nothen, M.M., Irvine, A.D., McLean, W.H., Deckert, S., Stephan, V., Schwarz, P., Aringer, M., Novak, N. and Weidinger, S. (2016) Atopic Dermatitis Is Associated with an Increased Risk for Rheumatoid Arthritis and Inflammatory Bowel Disease, and a Decreased Risk for Type 1 Diabetes. Journal of Allergy and Clinical Immunology, 137, 130-136. https://doi.org/10.1016/j.jaci.2015.06.029

[14] Boneberger, A., Weiss, E.H., Calvo, M. and Radon, K. (2012) Atopic Manifestations in Patients with Ulcerative Colitis: A Report from Chile. Journal of Investigational Allergology and Clinical Immunology, 22, 73-75.

[15] Dahten, A., Koch, C., Ernst, D., Schnoller, C., Hartmann, S. and Worm, M. (2008) Systemic PPAR $\gamma$ Ligation Inhibits Allergic Immune Response in the Skin. Journal of Investigative Dermatology, 128, 2211-2218. https://doi.org/10.1038/jid.2008.84

[16] Nishimura, T., Andoh, A., Hashimoto, T., Kobori, A., Tsujikawa, T. and Fujiyama, Y. (2010) Cellobiose Prevents the Development of Dextran Sulfate Sodium (DSS)Induced Experimental Colitis. Journal of Clinical Biochemistry and Nutrition, 46, 105-110.

[17] Park, L.S., Martin, U., Garka, K., Gliniak, B., Di Santo, J.P., Muller, W., Largaespada, D.A., Copeland, N.G., Jenkins, N.A., Farr, A.G., Ziegler, S.E., Morrissey, P.J., Paxton, R. and Sims, J.E. (2000) Cloning of the Murine Thymic Stromal Lymphopoietin (TSLP) Receptor. Journal of Experimental Medicine, 192, 659-669.

https://doi.org/10.1084/jem.192.5.659

[18] Yokoyama, S., Hiramoto, K., Koyama, M. and Ooi, K. (2014) Skin Disruption Is Associated with Indomethacin-Induced Small Intestinal Injury in Mice. Experimental Dermatology, 23, 659-663. https://doi.org/10.1111/exd.12499

[19] Hiramoto, K., Sugiyama, D., Takahashi, Y. and Mafune, E. (2016) The Amelioration Effect of Tranexamic Acid in Wrinkles Induced by Skin Dryness. Biomedicine \& Pharmacotherapy, 80, 16-22. https://doi.org/10.1016/j.biopha.2016.02.013

[20] Onodera, A., Yamashita, M., Endo, Y., Kawahara, M., Tofukuji, S., Hosokawa, H., Kanai, A., Suzuki, Y. and Nakayama, T. (2010) STAT6-Mediated Displacement of Polycomb by Trithorax Complex Establishes Long-Term Maintenance of GATA3 Expression in T Helper Type 2 Cells. Journal of Experimental Medicine, 207, 24932506. https://doi.org/10.1084/jem.20100760

[21] Korn, T., Bettelli, E., Oukka, M. and Kuchroo, V.K. (2009) IL-17 and Th17 Cells. Annual Review of Immunology, 27, 485-517. https://doi.org/10.1146/annurev.immunol.021908.132710

[22] Elson, C.O., Sarton, R.B., Tennyson, G.S. and Riddell, R.H. (1995) Experimental Models of Inflammatory Bowel Disease. Gastroenterology, 109, 1344-1367. https://doi.org/10.1016/0016-5085(95)90599-5

[23] Komekura, R., Kojima, T., Koizumi, J., Ogasawara, N., Kurose, M., Go, M., Harimaya, A., Murata, M., Tanaka, S., Chiba, H., Himi, T and Sawada, N. (2009) Thymic 
Stromal Lymphopoietin Enhances Tight-Junction Barrier Function of Humannosal Epithelial Cells. Cell and Tissue Research, 338, 283-293.

https://doi.org/10.1007/s00441-009-0855-1

[24] Liu, Y.J., Soumelis, V., Watanabe, N., Ito, T., Wang, Y.H., MalefytRde, W., Omori, M., Zhou, B. and Ziegler, S.F. (2007) TSLP: An Epithelial Cell Cytokine That Regulates T Cell Differentiation by Conditioning Dengritic Cell Maturation. Annual Review Immunology, 25, 193-219. https://doi.org/10.1146/annurev.immunol.25.022106.141718

[25] Allakhverdi, Z., Comeau, M.R., Jessup, H.K., Yoon, B.R., Brewer, A., Chartier, S., Paquette, N., Ziegler, S.F., Sarfati, M. and Delespesse, G. (2007) Thymic Stromal Lymphopoietin Is Released by Human Epithelial Cells in Response to Microbes, Trauma, or Inflammation and Potently Activates Mast Cells. Journal of Experimental Medicine, 204, 253-258. https://doi.org/10.1084/jem.20062211

[26] Nagata, Y., Kamijuku, H., Taniguchi, M., Ziegler, S. and Seino, K. (2007) Differential Role of Thymic Stromal Lymphopoietin in the Induction of Airway Hyperreactivity and Th2 Immune Response in Antigen-Induced Asthma with Respect to Natural Killer T Cell Function. International Archives of Allergy and Immunology, 144, 305-314. https://doi.org/10.1159/000106319

[27] Kitajima, M., Lee, H.C., Nakayama, T. and Ziegler, S.F. (2011) TSLP Enhances the Function of Helper Type 2 Cells. European Journal of Immunology, 41, 1862-1871. https://doi.org/10.1002/eji.201041195

[28] Bell, B.D., Kitajima, M., Larson, R.P., Stoklasek, T.A., Dang, K., Sakamoto, KG., Wagner, K.U., Kaplan, D.H., Reizis, B., Hennighausen, LH. and Ziegler, S.F. (2013) The Transcription Factor SRAT5 Is Critical in Dendritic Cells for the Development of $\mathrm{T}_{\mathrm{H}} 2$ but Not $\mathrm{T}_{\mathrm{H}} 1$ Responses. Nature Immunology, 14, 364-371. https://doi.org/10.1038/ni.2541

[29] Tezuka, H. and Ohteki, T. (2010) Regulation of Intestinal Homeostasis by Dendritic Cells. Immunological Reviews, 234, 247-258. https://doi.org/10.1111/j.0105-2896.2009.00872.x

[30] He, R. and Geha, R.S. (2010) Thymic Stromal Lymphopoietin. Annals of the New York Academy of Sciences, 1183, 13-24. https://doi.org/10.1111/j.1749-6632.2009.05128.x

[31] Li, J., Leyva-Castillo, J.M., Hener, P., Eisenmamm, A., Zaafouri, S., Jonca, N., Serre, G., Birling, M.C. and Li, M. (2016) Counterregulation between Thymic Stromal Lymphopoietin- and IL-23-Driven Immune Axes Shapes Skin Inflammation in Mice with Epidermal Barrier Defects. Journal of Allergy and Clinical Immunology, 138, 150-161. https://doi.org/10.1016/j.jaci.2016.01.013

[32] Spadoni, I., Iliev, I.D., Rossi, G. and Rescigno, M. (2012) Dendritic Cells Produce TSLP That Limits the Differentiation of Th17 Cells, Fosters Treg Development, and Protects against Colitis. Mucosal Immunology, 5, 184-193. https://doi.org/10.1038/mi.2011.64

[33] Yamamoto, T., Endo, Y. and Nakayama, T. (2016) Innate Immunity. Japanese Journal of Allergology, 65, 1-10. 
Submit or recommend next manuscript to SCIRP and we will provide best service for you:

Accepting pre-submission inquiries through Email, Facebook, LinkedIn, Twitter, etc. A wide selection of journals (inclusive of 9 subjects, more than 200 journals)

Providing 24-hour high-quality service

User-friendly online submission system

Fair and swift peer-review system

Efficient typesetting and proofreading procedure

Display of the result of downloads and visits, as well as the number of cited articles Maximum dissemination of your research work

Submit your manuscript at: http://papersubmission.scirp.org/

Or contact jbm@scirp.org 